\title{
Expanding the Industrial Design Space through Production Innovation(s)
}

\author{
Lisa Larsson \\ Dept. of Business Administration, Technology \\ and Social Sciences \\ Luleå University of Technology \\ Luleå, Sweden \\ lisa.larsson@1tu.se
}

\author{
David Romero \\ Center for Innovation in Design and Technology \\ Tecnológico de Monterrey \\ Mexico \\ david.romero.diaz@gmail.com
}

\begin{abstract}
Over the decades, manufacturing firms have tried to Design for Manufacturability merely by exhorting industrial design engineers to create more producible-designs. This is most often achieved by considering the available manufacturing system capability for the product development, and it is common to run into troubles in many cases due to barriers to integrate product definition and manufacturing operations. In this paper, authors aim to explore how production innovations (as new manufacturing capabilities) can contribute to an increased industrial design space for product design engineers, enabling more design freedom while still obtaining producibility through removing and/or loosening constraints over product designs. The findings of a series of industrial case studies presented in this paper show promising outcomes on how production innovations can influence positively the expansion of the solution space of industrial design engineers. In addition, manufacturing engineers are driven to explore new materials, new manufacturing processes and new manufacturing (working) methods to support product innovation.
\end{abstract}

Keywords-Industrial Design; Design for X; Design to X; Product Innovation; Manufacturing System; Production Innovation.

\section{INTRODUCTION}

Over the decades, manufacturing firms have tried to design for manufacturability merely by exhorting industrial design engineers to create more producible-designs by considering the available manufacturing system capability, using more or less integration between functions in the process. In many cases, there are barriers and discrepancies that prevent full integration of the development of the product and the production [1], since industrial design engineers have the tendency to focus more on performance of the product, while manufacturing engineers on production efficiency. In that context, the role of production development is considered as the development of new production solutions needed in the realization of a new product. Another side of production development is the development of new manufacturing technology and processes, named production innovations in this paper, which emerge, and are implemented traditionally, for increasing economic gains and productivity at the shop-floor. Limited attention has been given the view of 'production innovations' [2] as enablers for innovative product designs [3], even though manufacturing capability is recognized as an important input for early design phases in product development. Lewandowski et al. [4] argue that new technology and manufacturing processes need to be precedents for product development or be perfectly coordinated in a concurrent manner in order to frame the industrial design space.

The aim of this paper is to explore how production innovations, as described above, can contribute to an increased industrial design space for product design engineers, and in turn product innovation. Industrial cases of production innovations from a variety of manufacturing firms are analyzed using 'producibility factors' as the link between manufacturing system capability and product design.

This approach aims to provide manufacturing engineers the same status that industrial design engineers have as creative artists, not of product designs, but in this case of manufacturing systems, giving both the glamour of designing and engineering for innovation at product and manufacturing process(es) levels towards competitive advantages for the manufacturing firm in terms of industrial design and manufacturability.

The findings from the case studies presented in this paper show promising outcomes on how production innovations can influence positively the expansion of the solution space of industrial design engineers. These (new) possibilities may drive manufacturing engineers to explore new materials, new manufacturing processes and new manufacturing (working) methods to support product innovation by means of production innovation(s).

\section{Expanding the Solution Space for Product Design}

Design for eXcellence $(D f X)$ and Design to Properties (DtX) methodologies are both approaches for linking - product definition - to the available - manufacturing system capability hence increasing the manufacturability of a product design. Manufacturability is defined by [5] as "the relative ease with which a product or component can be produced, its simplicity, the straightforwardness of its configuration, the degree to which it minimizes labor, materials and overhead cost; and the freedom that its design has from inherent quality and processing problems".

Addressing the task at hand from both directions, Design for Manufacturability ( $D f M$ ) focuses on restraining the possible product definition space to the manufacturing system capability, while Design to Manufacturability (DtM) looks into how to create more 'freedom' in product definition, hence moving the borders of the manufacturing system capability space and expanding the actual product definition space (see Fig. 1). 


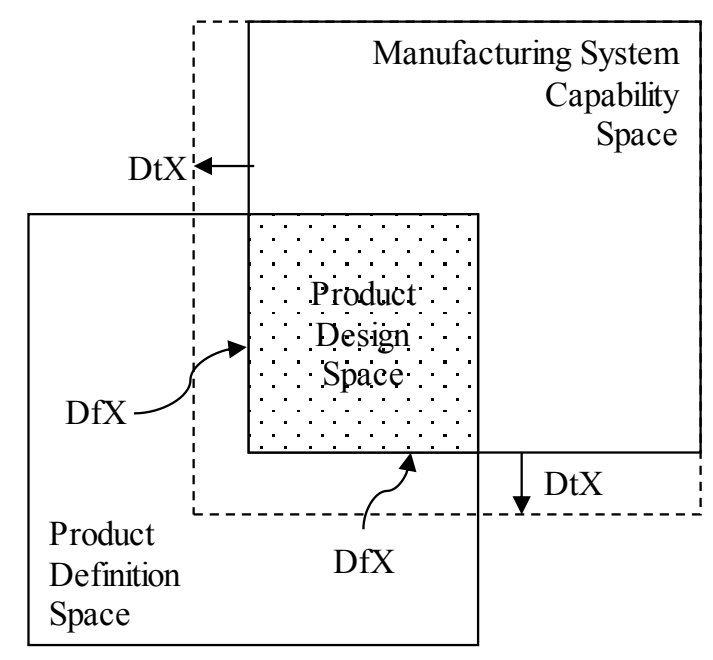

Fig. 1. Product Definition and Manufacturing System Capability Spaces Delimiting the Product Design Space (Adapted from [5])

The actual 'product definition' and 'manufacturing system capability space' is the overlapping area, as depicted in Fig. 1, of the product design space, which depends on the product portfolio and the manufacturing system capability space based on production and resource limitations [6].

\section{A. Design for Manufacturability eXcellence (DfX) for Industrial Design Engineers}

Traditionally, Design for eXcellence ( $\mathrm{f} f \mathrm{X})$ methodologies, as a set of design guidelines (e.g. Design for Manufacturing (DfM) and Design for Assembly (DfA)), have proposed different approaches and corresponding methods that help industrial design engineers to generate and apply technical knowledge to control, improve or even invent particular traits and attributes for a product design. The implementation of DfM and DfA have led to enormous benefits including simplification of products, reduction of manufacturing and assembly costs, and improvement of quality [7].

$D F M \& A$ methodologies have focused over the years on gathering numerous design rules and constraints for industrial design engineers to narrow their product designs to the available manufacturing technologies capabilities, disregarding in many cases the possibilities offered by production innovations to make possible product innovations ( $c f$. new product definitions). A recent example of a production innovation is the additive manufacturing technology, which is providing industrial design engineers with more geometry and functional freedom, as well as new synthesized materials with properties, for their product designs [8].

DfM methodologies intend to minimize the cost of production and time-to-market without compromising on the quality of the product, supporting in this way industrial design engineers with various requirements related to manufacturability. DfM methodologies describe the process of designing a product or component in order to facilitate its manufacturing. This includes a set of guidelines for material type and form selection, dimensional tolerances, and design and shape (e.g. DfM for Printed Circuit Boards, Integrated Circuits, CNC machining, Additive Manufacturing).

\section{B. Design to Manufacturability Properties (DtX) for} Manufacturing Engineers

More recently, Design to Properties (DtX) methodologies as a set of manufacturing technologies' parameters (e.g. Design to Cost (DtC) and Design to Quality (DtQ)) have emerged to propose different approaches and corresponding methods to help manufacturing engineers to design next generation manufacturing (production) systems.

Such manufacturing systems may include new materials (e.g. foams, coatings, metals, polymers, powders, etc.), new manufacturing hardware (e.g. factory layouts, jigs, fixtures and other tools), new manufacturing processes (e.g. additive and subtractive processes), and new manufacturing (working) methods (e.g. assembly processes). These are all capable of expanding the present solution space of product designs for producibility.

DtX methodologies concern with challenging manufacturing engineers to create or expand manufacturing technologies capabilities to fit the industrial design engineers' innovative product designs, so that the creativity of a product design does not exceed the creativity for finding a way to manufacture (cf. producibility) such product definition in a competitive way. A recent example is the development of smart materials for active disassembly in order to support eco-product designs (e.g. Design for Recycling (DfR) and Design for Disassembly (DfD)).

\section{Producibility: Bringing Together DESIGN FOR X AND DESIGN TO X}

According to [9], there are several approaches to manufacturing in design, and these approaches provide industrial design engineers with guidelines on how to design products to be 'producible'.

Producibility is defined by [10] as "the relative ease by which a product can be manufactured as measured in yield, cycle times, and the associated costs of options in (product) design, manufacturing processes, production and support, and tooling". Moreover, producibility is the "manufacturing capability to produce a product in a robust and efficient way to meet the design specifications for functions and reliability of the product" [11]. It advocates a strong link to product functions, characteristics and performance [11]. Therefore, it can be seen "as a property of product development and manufacturing systems that encapsulates the ability to produce a product within cost and schedule constraints, while maintaining a target level of quality and producing a product compliant with applicable requirements" [12]. Hence, 'producibility' can be considered as the outcome of a breath of design and manufacturing activities, as the missing link between product development and production operations, where producibility risk ( $c f$. production shortfalls) results from the incompatibility of product definition with the capability of its manufacturing system [12]. Detailed product definition and manufacturing processes variation have traditionally been focus areas for understanding risk for producibility losses [12]. 
According to [11], the term manufacturability is often used in the producibility definitions and context, though it is very similar in many cases, there is one aspect of producibility that can be identified as a distinction between the two. In producibility, there is a strong link to the product functions, characteristics and performance, while in contrast in manufacturability, the product function and its characteristics are of less concern, thus focusing on production optimization instead. The reason is that the maturity of product and manufacturing process technology is not always the same.

Design for Producibility (DfP) is the process in which a systematic method is used to reach the required functional properties of a product at the same time as good compliance with its manufacturing system is ensured [6]. A distinction can be made between DfP and DfM, where DfP includes [6]:

(a) the specification of requirements and metrics for the intended manufacturing processes - not for average processes, and

(b) a holistic view where the manufacturing processes and the product properties are treated as a whole - not analyzed as separate parts, also known as Integrated Product and Process Development (IPPD) framework.

Knowledge about the manufacturing system is essential in carrying out DfP. According to [6], DfP has to be performed with 'specified objectives' that need to be defined as 'measures of producibility'. Seven considerations are suggested by [13] as suitable for assessing the effect that a certain product design on each phase of the product lifecycle, including the manufacturing activity:

(1) production cost,

(2) quality,

(3) flexibility,

(4) risk,

(5) lead-time,

(6) efficiency, and

(7) environmental effects.

These considerations are closely linked to parameters frequently used for assessing a manufacturing system performance [14]:

(a) productivity,

(b) efficiency,

(c) cost,

(d) quality, and

(e) time.

Improving these parameters are also the most common intentions in production development.

In this sense, authors propose the use of DfX methodologies as a set of specified objectives for a product definition ( $c f$. particular traits and attributes) by industrial design engineers. At the same time, the use of DtX methodologies are proposed as a set of measures of producibility for describing a manufacturing system capability ( $c f$. performance) by manufacturing engineers. In this way, both engineering groups (design and manufacturing) will be able to converge in a coherent and guided way in the product design space, linking product and production innovation (e.g. [15] and [16]).
Table I aims to depict the underlying product design manufacturing process interactions that exist in a product development.

Table I. Corresponding Product Design and Proposed Manufacturing Design Methodologies

\begin{tabular}{|c|c|c|}
\hline Parameter & $\begin{array}{l}\text { Product Design } \\
\text { Methodologies }\end{array}$ & $\begin{array}{l}\text { Manufacturing Design } \\
\text { Methodologies } \\
\text { (Proposed) }\end{array}$ \\
\hline $\begin{array}{l}\text { Production } \\
\text { Cost }\end{array}$ & $\begin{array}{c}\text { Design for } \\
\text { Cost (DfC) - } \\
\text { Establishes rigorous cost } \\
\text { goals to design engineers } \\
\text { for a NPD, within a given } \\
\text { budget and (product) } \\
\text { performance } \\
\text { requirements [17]. }\end{array}$ & $\begin{array}{c}\text { Design to production } \\
\text { Cost (DtC) - } \\
\text { Development of } \\
\text { production innovations } \\
\text { (e.g. materials, tooling, } \\
\text { methods, systems, etc.) } \\
\text { capable of contributing to } \\
\text { reduced production costs } \\
\text { without compromising } \\
\text { the innovation potential } \\
\text { in new product definitions. }\end{array}$ \\
\hline Quality & $\begin{array}{c}\text { Design for } \\
\text { Quality (DfQ) - } \\
\text { Driving a product design } \\
\text { that industrial design } \\
\text { engineers will need to } \\
\text { meet according to their } \\
\text { proposed product } \\
\text { definition. }\end{array}$ & $\begin{array}{c}\text { Design to } \\
\text { Quality (DtQ) - } \\
\text { Development of } \\
\text { manufacturing process } \\
\text { (cf. machine tools) } \\
\text { capabilities with higher } \\
\text { compliance of geometric } \\
\text { dimensioning and } \\
\text { tolerancing (e.g. precision } \\
\text { engineering and } \\
\text { manufacturing). }\end{array}$ \\
\hline Flexibility & $\begin{array}{c}\text { Design for } \\
\text { Standardization (DfS) - } \\
\text { Aims to standardize parts } \\
\text { in a product definition } \\
\text { with the aim of designing } \\
\text { product platforms } \\
\text { that could support } \\
\text { the re-utilization of parts } \\
\text { across a product family } \\
\text { and/or product } \\
\text { generations. }\end{array}$ & $\begin{array}{c}\text { Design to } \\
\text { Flexibility (DtF) - } \\
\text { Creating or developing } \\
\text { manufacturing flexibility } \\
\text { (cf. machine flexibility), } \\
\text { so the manufacturing } \\
\text { system's capability allows } \\
\text { to be changed to produce } \\
\text { new or different product } \\
\text { types. }\end{array}$ \\
\hline Risk & $\begin{array}{c}\text { Design for Minimum } \\
\text { Risk (DfMR) - } \\
\text { Designing the safest and } \\
\text { innovative product } \\
\text { that can accomplish } \\
\text { its expected performance } \\
\text { in terms of } \\
\text { e.g. functionality, } \\
\text { aesthetics, ergonomics, } \\
\text { safety, reliability, } \\
\text { etc. [17]. }\end{array}$ & $\begin{array}{l}\text { Design to Minimum } \\
\text { Risk (DtMR) - } \\
\text { Managing risk when } \\
\text { ramping-up new } \\
\text { production technology } \\
\text { promising manufacturing } \\
\text { capability to deliver } \\
\text { the expected performance } \\
\text { (viz. production } \\
\text { throughput, efficiency and } \\
\text { quality) without adding } \\
\text { any deficiencies to } \\
\text { the product design [19]. }\end{array}$ \\
\hline Lead-Time & $\begin{array}{l}\text { Design for Short Time to } \\
\text { Market (DfSTTM) - } \\
\text { Support industrial design } \\
\text { engineers in the decision } \\
\text { between improve an } \\
\text { existing product or } \\
\text { develop a new one in order } \\
\text { to quickly respond to } \\
\text { customers' needs [18]. }\end{array}$ & $\begin{array}{c}\text { Design to } \\
\text { Lead-Time (DtLT) - } \\
\text { Creating or developing } \\
\text { manufacturing agility, } \\
\text { so the manufacturing } \\
\text { system's capability } \\
\text { enables a quick response } \\
\text { to customer needs and } \\
\text { market changes while } \\
\text { still controlling costs } \\
\text { and quality. }\end{array}$ \\
\hline
\end{tabular}




\begin{tabular}{|c|c|c|}
\hline Efficiency & $\begin{array}{c}\text { Design for } \\
\text { Reliability (DfR) - } \\
\text { Aims to guarantee that } \\
\text { the work of industrial } \\
\text { design engineers will } \\
\text { comply with its intended } \\
\text { function for a designed } \\
\text { period-of-time without } \\
\text { failure under specified } \\
\text { condition [18]. }\end{array}$ & $\begin{array}{l}\text { Design to } \\
\text { Efficiency (DtEF) - } \\
\text { Reducing waste of } \\
\text { resources in production } \\
\text { for manufacturing } \\
\text { engineers. }\end{array}$ \\
\hline $\begin{array}{c}\text { Environmental } \\
\text { Effects }\end{array}$ & $\begin{array}{c}\text { Design for } \\
\text { Environment (DfE) - } \\
\text { Encompassing various } \\
\text { design tools for industrial } \\
\text { design engineers to reduce } \\
\text { the overall environmental } \\
\text { impact of a product, where } \\
\text { impacts are considered } \\
\text { across its lifecycle [18]. }\end{array}$ & $\begin{array}{c}\text { Design to } \\
\text { Environmental Effects } \\
\text { (DtEE) - } \\
\text { Develop manufacturing } \\
\text { systems capable of } \\
\text { producing products } \\
\text { with little to none } \\
\text { negative effects on } \\
\text { the environment. }\end{array}$ \\
\hline
\end{tabular}

\section{RESEARCH DESIGN}

A case study approach [23] was applied to investigate in depth and obtain rich data of innovative development projects in manufacturing processes and their effects on the manufacturing process and product design. Cases, i.e. production development projects, were selected through purposive sampling [24], selecting influential innovations in manufacturing processes where the intricacies of the production innovations and their possible effects could be revealed.

Data collection was conducted primarily through interviews with respondents (the interviewees) that were in some way involved in development projects aiming for production innovations; either in certain stages or through the entire project (see Table II). The interviews were semi-structured to ensure rich content and to obtain the interviewees perception on how 'production innovations' have contributed to 'product innovations', and which were the outcomes and the values these 'production innovations' added to both parties, industrial design engineers and manufacturing engineers. Questions were asked regarding the trigger or initiating factor for the production innovations, e.g., which were the outcomes (viz. innovations) of the production development projects and whom the outcomes affected (viz. industrial design engineers and/or manufacturing engineers).

Table II. Respondent Information

\begin{tabular}{|c|c|c|}
\hline Respondent & Case & Role \\
\hline 1 & A & Department Manager R\&D \\
\hline 2 & A & Department Manager Bridge Construction \\
\hline 3 & A & Structural Bridge Engineer \\
\hline 4 & B & Factory Manager \\
\hline 5 & B & Academic Representative \\
\hline 6 & B & Production Manager \\
\hline 7 & C & Project Manager [R\&D] \\
\hline 8 & C & Business Development \& Marketing Manager \\
\hline 9 & C & Production Developer \\
\hline 10 & C & Chief Engineer \\
\hline 11 & C & Production Manager \\
\hline 12 & D & Product Developer \\
\hline 13 & D \\
\hline
\end{tabular}

Secondary data on each manufacturing firm's business environment and strategy were collected from publically available sources and internal documentation. This triangulation of data provided complementation, interpretation and, to some degree, validation of the interview data.

The analysis follows the steps for qualitative research proposed by [25]: (a) data reduction, (b) data display, and (c) conclusion drawing and verification.

Data reduction was done through summarizing the interviews and transferring these into a database to sharpen, sort, focus and organize the data. This was followed by analysis and coding of the material in relation to producibility factors and effect on product design space, first on single case level and then crosscase to find common or differentiating characteristics according to the proposed method by [17]. Using manufacturing system performance parameters as the link between the manufacturing system and manufacturability of a product. Data was then displayed in tables to see patterns and be able to draw conclusions. During the conclusion drawing, iterations between emerging results, theory, and empirical data for the case study were performed to consolidate the developing conclusions [23].

\section{CASE DESCRIPTIONS}

A brief presentation of the manufacturing firms and their production development projects, including the initiating trigger and developed solutions (innovations), are described in order to understand the setting in which the firms operate and the market they design and produce for.

\section{A. Case A: New Production Method for Bridges Construction}

The firm is one of the leading contractors in Northern Europe with around 18,000 employees; operating in development and construction of roads and infrastructure, residential and commercial properties as well as industrial facilities and public buildings. The firm strives to renew the construction industry by being the leading actor in the markets in which it operates, offering sustainable solutions, and becoming the customer's first choice. In Sweden, bridges are traditionally constructed on-site in a 'craftsmanship' manner involving wooden formwork, reinforcement and concrete casting. The need for faster, more cost-efficient methods led to the bridge concept studied, which includes assembly of prefabricated concrete and stainless steel structures. Consequently, the solution contains both advanced technology as well as a new way of constructing, affecting both production and product definition.

\section{B. Case B: Process Changes in Industrialised Apartments Construction}

Sweden's leading company in industrialized building of apartment blocks is a family owned business, which started as a small sawmill in 1924 and has since developed into a modern and high tech production site with 250 employees. The vision of being customers' first choice for construction and living is to be reached through strategic goals in four areas: product, process, brand and leadership/employee-ship.

The starting point of the development project was a need for better quality in the bathroom floors, which encountered problems in transport and needed corrective measures once assembled into place. The traditional method of using levelling 
compound and water proofing in steps was also very time consuming and not suitable for the production line. The solution to these problems became a molded fiberglass basin, waterproof and with integrated drain, which solved the quality issues and replaced many steps and waiting times in manufacturing process with an assembly activity.

\section{Case C: New Technology in Aerospace Manufacturing}

The vision of the studied aerospace firm is "being the best value solution for our customers worldwide to meet aerospace and defense needs". The studied firm changed ownership 2012 and became part of a global company with business in Europe, North America and Asia. The main business of this aerospace firm is the design and manufacture of complex, highperformance, high-value integrated metallic and composite assemblies for aero-structures and engine products. The studied production development project was set out to search and point out improvement potentials for the current rocket nozzle manufacturing, and to investigate and develop new and better manufacturing designs and processes. The main objectives of the project were decreased lead-time, improved flexibility and set-up time, while keeping low cost and maintain or improve reliability of the product. This led to the development of a new manufacturing method of a space rocket nozzle, welding together layers of sheet metal with milled out channels instead of metal tubes welded together side by side to create a structure where coolant flows through. This manufacturing method consists of several different sub-technologies, which are also transferred to and used in other products within the firm.

\section{Case D: Twisted Holes in Drill Manufacturing}

This study is conducted within a company that supplies cutting tools and services to the metal working industry. The company is a market leader and is represented in 130 countries. Moreover, the company invests heavily in $R \& D$, compared to the industry standard, and introduces 2,500 new products every year. Although the case company mainly supplies tools and tooling systems to its customers, the focus of the company is to increase the customers' productivity and profitability through a deep understanding of their processes. The customer base is mainly industrial companies, e.g. within automotive, aerospace and energy sectors.

The metal cutting industry is constantly trying to improve its methods to obtain better quality and efficiency. The drill developed in this project solved an issue with chip control in drilling. This was possible through the development of a new method for making twisted coolant holes, permitting a different geometry of the drill.

\section{DISCUSSION}

The main objectives of the studied production development projects were to find ways to produce products with reduced production cost and improved quality. Although the projects concern production innovations, the initiating factor was a need for or an innovation opportunity of improved manufacturing capability to produce a product. As the studied manufacturing technologies developed and matured, it became possible to integrate production and product development and obtain higher producibility.
To DfP, both DtX and DfX methodologies were applied in the studied cases to maintain or increase performance in the specified requirements (viz. producibility factors) for the manufacturing process and adapt product design to the emerging industrial design space. For example:

In Case $\mathrm{A}$ and Case $\mathrm{B}$, industrial design engineers and manufacturing engineers were limited to certain requirements in accordance to DfM before the 'innovations'. The production innovations with their new performance in producibility factors opened up for new product design possibilities.

In Case A, the product design concept of the bridge had to match the prefabrication method chosen mainly due to Design to Cost (DtC) and Design for Lead-Time (DfLT), hence Design for Manufacturing (DfA) and Design for Assembly was applied to design a product (bridge) that was modular and assemblyfriendly.

Furthermore, the mixing of materials (steel and concrete) in the manufacturing method make it possible to slim the dimensions of the bridge when desired to obtain an aesthetically pleasing product or better prerequisites to adapt a bridge to its environment (geographical and geotechnical), hence increases the number of possible designs.

In Case B, the manufacturing methods used in industrialized construction systems are conventional methods transferred into an industrialized setting, still with quite low performance on producibility factors like lead-time. The bathroom floors were previously manufactured according to conventional methods. This was not only a time-consuming effort disturbing the whole production process, but also causing quality issues as this type of floor was not suitable to be transported, an inevitable part of the process of prefabrication and assembly. The development of this solution was a joint effort of developing both the fiberglass basin and the manufacturing process - using DtX to increase the performance on producibility factors like lead-time, quality and production cost by adapting the production system to the industrialized setting and DfX to design a fiberglass basin suitable for the manufacturing process. These findings support [6] statement that DfP involve a holistic view of the manufacturing process and product properties.

In Case $\mathrm{C}$, the previous manufacturing method for the space rocket nozzle had restrictions in dimensions of the product. The restrictions came from the forming and welding of tubes together in a spiral pattern on a bell-shaped cast, a method that for some dimensions were not possible to make without compromising the product functionality and quality. With the new manufacturing method, this restriction in dimensions were no longer an issue as the method is applicable to all or at least many more dimensions opening up for product design space to push product performance further.

Similar to Case C, in the Case D, existing manufacturing methods had restrictions on possible dimensions of the product. In this case, the main objective was not cutting cost in production, but rather seizing the opportunities for increased performance and quality that this technology could bring to the product design. The manufacturing method for twisted holes made it possible to design and produce drills of new dimensions, using twisted cooling channels placed in the flanges. 
The superior performance of this new type of drill together with the low production cost made this a successful coalition of DfX and DtM.

The positive effects on producibility factors and product design space in one perspective can also have a contradictory side. As seen in Case A and Case B, increased performance in producibility and an expansion of the product design space in one direction can also infer a further limitation of the design space in another direction. For example, by trading the resource consuming conventional construction methods for more efficient prefabrication methods that expand the product design space by bringing possibilities of slimmer designs, some new constraints are put on industrial design engineers in adapting designs for modularity. However, using combinations of manufacturing methods wisely can bring the benefits without seeing the downsides.

A summary of each case's effects on the different producibility factors is presented in Table III. As the effects on these factors are interlinked with each other, they overlap to some extent - e.g. lead-time reductions contribute to reduce production cost.

Table III. Production Innovation Effects on Producibility Factors

\begin{tabular}{|c|c|c|c|c|}
\hline $\begin{array}{l}\text { Producibility } \\
\text { Factor }\end{array}$ & Case A & Case B & Case C & Case D \\
\hline $\begin{array}{l}\text { Production } \\
\text { Cost }\end{array}$ & $\begin{array}{c}\text { Reduced } \\
\text { bridge } \\
\text { construction } \\
\text { project } \\
\text { lifecycle cost } \\
+ \\
\text { Improved } \\
\text { construction } \\
\text { process }\end{array}$ & $\begin{array}{l}\text { Improved } \\
\text { industrialized } \\
\text { apartments } \\
\text { construction } \\
\text { process }\end{array}$ & $\begin{array}{c}\text { Improved } \\
\text { production } \\
\text { process } \\
+ \\
\text { Reduced } \\
\text { labor cost }\end{array}$ & $\begin{array}{c}\text { Less } \\
\text { expensive } \\
\text { cuttings tools } \\
+ \\
\text { Less } \\
\text { expensive } \\
\text { drilling } \\
\text { services }\end{array}$ \\
\hline Quality & $\begin{array}{l}\text { Higher service } \\
\text { (construction } \\
\text { process) } \\
\text { quality }\end{array}$ & $\begin{array}{l}\text { Higher } \\
\text { product } \\
\text { (apartment) } \\
\text { quality }\end{array}$ & $\begin{array}{c}\text { Higher } \\
\text { product } \\
\text { (assembly) } \\
\text { quality }\end{array}$ & $\begin{array}{l}\text { Higher } \\
\text { product } \\
\text { (cutting } \\
\text { tools) \& } \\
\text { service } \\
\text { (drilling } \\
\text { precision) } \\
\text { quality }\end{array}$ \\
\hline Flexibility & $\begin{array}{l}\text { Maintained } \\
\text { flexibility } \\
\text { through } \\
\text { modularity }\end{array}$ & $\begin{array}{l}\text { Maintained } \\
\text { flexibility } \\
\text { through } \\
\text { component } \\
\text { variants }\end{array}$ & $\begin{array}{l}\text { Faster } \\
\text { response } \\
\text { to changes in } \\
\text { product } \\
\text { design }\end{array}$ & $\begin{array}{c}\text { More } \\
\text { product } \\
\text { variants } \\
\text { possible }\end{array}$ \\
\hline Risk & $\begin{array}{c}\text { Improved } \\
\text { control } \\
\text { over } \\
\text { the } \\
\text { construction } \\
\text { process }\end{array}$ & $\begin{array}{c}\text { Less risk } \\
\text { of mistakes } \\
\text { in production } \\
\text { process }\end{array}$ & $\begin{array}{c}\text { Improved } \\
\text { production } \\
\text { stability } \\
+ \\
\text { less } \\
\text { deformation } \\
\text { problems }\end{array}$ & $\begin{array}{l}\text { Improved } \\
\text { drilling } \\
\text { precision }\end{array}$ \\
\hline Lead-time & $\begin{array}{l}\text { Reduced } \\
\text { bridge } \\
\text { construction } \\
\text { lead-time } \\
\text { due to use of } \\
\text { prefabricates }\end{array}$ & $\begin{array}{c}\text { Reduced } \\
\text { assemblies } \\
\text { manufacturin } \\
\text { g lead-time }\end{array}$ & $\begin{array}{c}\text { Reduced } \\
\text { development } \\
\text { lead-time } \\
+ \\
\text { Reduced } \\
\text { manufacturin } \\
\text { g lead-time }\end{array}$ & $\begin{array}{l}\text { Increased } \\
\text { drilling } \\
\text { speed for } \\
\text { customers }\end{array}$ \\
\hline
\end{tabular}

\begin{tabular}{|c|c|c|c|c|}
\hline Efficiency & $\begin{array}{l}\text { Construction } \\
\text { process }\end{array}$ & $\begin{array}{l}\text { Production } \\
\text { process }\end{array}$ & $\begin{array}{c}\text { Production } \\
\text { process } \\
+ \\
\text { Welding } \\
\text { speed } \\
+ \\
\text { Automation }\end{array}$ & $\begin{array}{l}\text { Drilling } \\
\text { process }\end{array}$ \\
\hline $\begin{array}{l}\text { Environmenta } \\
1 \text { Effects }\end{array}$ & $\begin{array}{c}\text { Less material } \\
\text { use } \\
+ \\
\text { Reduced } \\
\text { maintenance }\end{array}$ & $\begin{array}{c}\text { Material } \\
\text { with less } \\
\text { environmenta } \\
1 \text { effect } \\
+ \\
\text { Longer } \\
\text { product } \\
\text { lifetime }\end{array}$ & $\begin{array}{c}\text { Less material } \\
\text { use } \\
+ \\
\text { Reduced } \\
\text { weight } \\
\text { (less fuel } \\
\text { consumption } \\
\text { in use) }\end{array}$ & $\begin{array}{c}\text { Extended } \\
\text { product } \\
\text { lifetime }\end{array}$ \\
\hline
\end{tabular}

By using both DfC and DtC design methods to support production cost engineering (including material, energy, labor, machine costs, etc.), it can be possible to design and engineer a technically feasible and financially viable ( $c f$. cost competitive) product design space, where 'innovative' manufacturing technologies will help to reduce production cost without trade-offs with the product design or even with contributions to product definition space. Such is the example of the Case A, where construction project lifecycle costs for a bridge were reduced by introducing an innovative prefabrication method to cut-back on labor cost and new material mixes to cut-down on raw materials cost. Similarly, the Case B was able to reduce labor cost by introducing a novel process of prefabrication and assembly for tile flooring. In the Case $\mathrm{C}$, a new production process based on novel technologies for welding and milling helped to reduce again labor cost in the production of space rocket nozzles, and for the Case $\mathrm{D}$, it was a new manufacturing method and its novel machine tool, the one that made possible to reduce tooling costs in drilling services.

By merging both DfQ and DtQ design methods, it is expected to improve the technical feasibility of the product design space, in other words from CAD output to manufacturing. What has been designed according to product specifications and standards will be manufactured with geometric dimensioning precision or in the worst case within permissible engineering tolerances. Such are the examples of Cases A and B, where the overall quality of the final products was increased, a bridge and a bathroom floor respectively, thanks to the use of prefabricated building components that were developed under controlled conditions. In the Case $\mathrm{C}$, a higher quality level in the production of space rocket nozzles was achived because of the introduction of a new production process based on a novel welding technology causing less deformation and weld starts/stops, and in the Case D, due to the development of a method for making twisted coolant holes in a drill, the developed drill performs with higher precision.

By combining both DfS and DtF design methods, it is expected to enable some mass-customization (MC) possibilities for the product design space. Such are the examples in the Cases $\mathrm{A}$ and $\mathrm{B}$, where the use of prefabricated building components increased the standardization of components, but flexibility was maintained through modularity. In the Cases $\mathrm{C}$ and $\mathrm{D}$, the introduction of new methods and technologies helped to offer certain level of MC in terms of providing more possible dimensional variants of the products. 
By mitigating risk by means of DfMR in product related failure modes and DtMR for managing risk in the ramp-up of new manufacturing processes, it is expected to improve production competency, including capability and capacity, without trade-offs with product quality. Such is the example of Case A, where the use of prefabricated building components, developed under controlled conditions, reduced risks of quality problems and delays during the construction process. In the Case $\mathrm{B}$, the use of a novel process of prefabrication and assembly for tile flooring helped to reduce quality issues in the raw material and installation of the floors. In the Case $\mathrm{C}$, the introduction of a new process based on a novel welding technology without weld starts and stops helped to eliminate problems and defects with welded joints, and in the Case $\mathrm{D}$, the new drilling machine tool improved its drilling precision for twisted holes significally reducing the number of holes out of tolerances.

By unifying the strengths of a product definition designed for short-time to market (DfTTM) and an agile manufacturing system (DtLT), the solution space of the product design will offer a competitive advantage based on rapid product design and development. Such is the example of Cases A and B, where bridge construction and floor production lead-times were reduced due to the use of prefabricated building components. In Case C, the speed (agility) of the novel welding technology improved the lead-time of the production process. Similary, in the Case D, the developed drilling machine tool enabled higher speed (agility) which positively influenced the lead-time.

By combining both DfR and DfEF design methods, product design and engineering reliability will improve and contribute to production efficiency by avoiding reworks due to unmet specifications by the manufacturing system. Such is the example of Cases A, B, C and D, where the novel bridge construction, flooring, welding and drilling processes respectively, achieved new efficiency levels (leaness) by reducing reworks and their related waste types.

By advancing sustainable manufacturing capabilities through DfE and DtEE, it is expected to improve the environmental performance of manufactured products and their production systems. Such is the example of Cases A, B, C and D, where lean design and lean manufacturing principles were applied to reduce waste during the beginning of the products' lifecycle ( $c f$. design, engineering and manufacturing), and considerations were taken for products' lifetime extension during their middleof-life (e.g. servitization) and for their environmental-friendly handling at their end-of-life.

In addition, manufacturing engineers and their production innovations have been and will become even more important for the expansion of the solution space for product designs as products become more sophisticated in their definitions and shorter in their lifecycles. Both trends stress the need for a convergent guidance from DfX and DtX methodologies for industrial design engineers and manufacturing engineers to enable faster design cycles and agile and flexible manufacturing capabilities.

\section{CONCLUDING REMARKS}

The aim of this paper is to explore how production innovations, as described above, can contribute to an increased product design space for industrial design engineers, and in turn product innovation.

As our results indicate, production innovation can deliver an expansion of the product design space through delivering better performance in producibility factors and enabling new product definitions.

Innovative developments in manufacturing (production) systems (e.g. materials, tooling, methods, systems, etc.), also known as 'production innovations', can contribute through increased manufacturing system performance to an enhanced manufacturability and producibility, making technically feasible and financially viable new product developments (NPDs). It is therefore valuable to consider the potentials of production innovations to create or expand product design spaces instead of only focusing on 'design for manufacturability' that is adapting product definitions to the existing product design space framed by manufacturing capability. However, increased performance in producibility and an expansion of the product design space in one direction can also infer further constraints of the design space in another direction. Considering this ability of production innovations to influence the product design space, it may also have a considerable impact on the competitiveness of manufacturing firms, as another tool for increased innovativeness is presented.

\section{ACKNOWLEDGMENTS}

The studies presented in this paper is a part of the Production Innovation project, funded by VINNOVA.

The authors gratefully acknowledge the case companies and the participants of the studies for their valuable time and openness to share their experiences.

\section{REFERENCES}

[1] M. Vielhaber and P. Stoffels, P., "Product Development vs. Production Development," Procedia CIRP, Vol. 21, pp. 252-257, 2014.

[2] D. Romero, L. Larsson, A. Öhrwall Rönnbäck and J. Stahre., "Strategizing for Production Innovation," The Path to Intelligent, Collaborative and Sustianable Manufacturing, 2017 (To Appear).

[3] J. Lessing, L. Stehn and A. Ekholm, "Industrialised House-Building Development and Conceptual Orientation of the Field," Construction Innovation, Vol. 15, No. 3, pp. 378-399, 2015.

[4] C. Levandowski, D. Raudberget and H. Johannesson. "Set-based Concurrent Engineering for Early Phases in Platform Development," Proceedings of the 21st ISPE Inc. International Conference on Concurrent Engineering, CE 2014, pp. 564-576, 2014.

[5] J.G. Bralla, "Design for Manufacturability: Handbook," Ed., New York: McGraw-Hill, 1999.

[6] F. Elgh and M. Cederfeldt, "Cost-based Producibility Assessment: Analysis and Synthesis Approaches through Design Automation," Journal of Engineering Design, Vol. 19, No. 2, pp. 113-130, 2008.

[7] T-C. Kuo, S.H. Huang and H-C. Zhang, "Design for Manufacture and Design for ' $\mathrm{X}$ ': Concepts, Applications, and Perspectives," Computers \& Industrial Engineering, Vol. 41, No. 3, pp. 241-260, 2001.

[8] I. Gibson, D.W. Rosen and B. Stucker, "Additive Manufacturing Technologies: Rapid Prototyping to Direct Digital Manufacturing," 2nd Edition, New York, Springer, 2015. 
[9] J. Landahl, C. Levandowski, H. Johannesson, R. Söderberg, K. Wärmefjord, J.S. Carlson, J. Kressin, O. Isaksson and J. Vallhagen, "Using Product and Manufacturing System Platforms to Generate Producible Product Variants," Procedia CIRP, Vol. 44, pp. 61-66, 2016.

[10] Best Manufacturing Practices Center of Excellence, "Producibility System Guidelines for Successful Companies: The Five Steps to Success," Best Manufacturing Practices: College Park, MD, USA, NAVSO P3687, 1999.

[11] J. Vallhagen, J. Madrid, R. Söderberg and K. Wärmefjord, “An Approach for Producibility and DFM-Methodology in Aerospace Engine Component Development," Procedia CIRP, Vol. 11,pp. 151-156, 2016.

[12] A.J. Ball, "Identification of Leading Indicators for Producibility Risk in Early-Stage Aerospace Product Development," Doctoral Dissertation, Massachusetts Institute of Technology (MIT), 2015.

[13] F. Eureka, "Design for Manufacture - DFM, Guide for Improving the Manufacturability of Industrial Products," Fabricius, F. (Ed.), Institute for Product Development, Lyngby, Denmark, 1994.

[14] M. Bellgran and E.K. Säfsten, "Production Development: Design and Operation of Production Systems," Springer Science \& Business Media, 2009.

[15] P.M. Milling and J. Stumpfe, "Product and Process Innovation: A System Dynamics-Based Analysis of the Interdependencies," 18th International Conference of the System Dynamics Society, Bergen, Norway, 2000.
[16] J. Stumpfe, "Product Design and Manufacturing Processes: Dynamic Implications for Innovation Management," 19th International Conference of the System Dynamics Society, Atlanta, Georgia, USA, 2001.

[17] G. Pahl and W. Beitz, "Engineering Design - A Systematic Approach," 2nd Edition, London: Springer, 1996.

[18] J.G. Bralla, "Design for Excellence,” New York: McGraw-Hill, 1996.

[19] S. Elstner and D. Krause, "Methodical Approach for Consideration of Ramp-up Risks in the Product Development of Complex Products," Procedia CIRP, Vol. 20, pp. 20-25, 2014.

[20] D. Vazquez-Bustelo, L. Avella and E. Fernandez, "Agility Drivers, Enablers and Outcomes," International Journal of Operations \& Production Management, Vol. 27, No. 12, pp. 1303-1332, 2007.

[21] J.P. Womack, D.T. Jones and D. Roos, "Machine that Changed the World," Simon and Schuster, 1990.

[22] R.K. Yin, "Case Study Research: Design and Methods," Sage Publications, 2013.

[23] K.M. Eisenhardt and M.E. Graebner, "Theory Building from Cases: Opportunities and Challenges," Academy of Management Journal, Vol. 50, No. 1, pp. 25-32, 2008.

[24] M.B. Miles and A.M. Huberman, "Drawing Valid Meaning from Qualitative Data: Toward a Shared Craft," Educational Researcher, Vol. 13, No. 5, pp. 20-30, 1984. 